\title{
Zastosowanie ultrasonografii przezklatkowej płuc w różnicowaniu kardiologicznych i niekardiologicznych przyczyn duszności
}

\section{The usefulness of transthoracic chest ultrasound in differentiation of cardiological and non-cardiological dyspnea}

Tomasz Olesiewicz, Małgorzata Knapp, Agnieszka Tycińska, Robert Sawicki, Anna Lisowska

Klinika Kardiologii Uniwersytetu Medycznego w Białymstoku

\section{Streszczenie}

W kardiologii echokardiografia jest podstawowym, powszechnie wykorzystywanym narzędziem diagnostycznym. Przez wiele lat panowało przekonanie o małej przydatności ultradźwięków w diagnostyce narządów powietrznych, takich jak płuca. Okazuje się jednak, że badanie ultrasonograficzne płuc jest łatwą do wykorzystania metodą diagnostyczną zarówno w warunkach pracowni ultrasonograficznej, jak i przyłóżkowo w warunkach sali intensywnego nadzoru kardiologicznego. Pozwala na ustalenie w krótkim czasie wstępnego rozpoznania u pacjentów z ostrą niewydolnością oddechową, jeszcze przed wykonaniem badań rentgenowskich. Wielokrotne powtarzanie badania umożliwia monitorowanie efektów prowadzonej terapii. W artykule podsumowano aktualny stan wiedzy dotyczący zastosowania tej techniki ultrasonograficznej.

Słowa kluczowe: ultrasonografia przezklatkowa, duszność sercowa i pozasercowa

Folia Cardiologica 2017; 12, 5: 459-466

\section{Wstęp}

Celem niniejszej pracy jest przedstawienie zagadnień związanych z badaniem ultrasonograficznym (USG) płuc i zastosowaniem tej metody do szybkiej diagnostyki różnicowej przyczyn duszności. Aparatura ultrasonograficzna jest powszechnie używana na oddziałach szpitalnych. Stała się również standardowym wyposażeniem sal operacyjnych, oddziałów intensywnej terapii oraz szpitalnych oddziałów ratunkowych. Stale rośnie liczba lekarzy różnych specjalności posługujących się tą metodą diagnostyczną. Powszechnie wykorzystuje się ją w monitorowaniu stanu klinicznego pacjenta w ciężkim stanie ogólnym, po urazach, w czasie resuscytacji, przy przeprowadzaniu procedur inwazyjnych, takich jak kaniulacja naczyń, torakocenteza, perik- ardiocenteza lub znieczulenie regionalne. Brak szkodliwego wpływu fal ultradźwiękowych na pacjenta daje możliwość wielokrotnego powtarzania badania w celu kontrolowania postępu choroby lub efektów terapii. Rozwój technologiczny sprawił, że firmy produkujące ultrasonografy oferuja aparaty wysokiej jakości o małych gabarytach. Dzięki kompaktowym rozmiarom możliwe jest wykonanie badania nawet w trudnych warunkach, ciasnych pomieszczeniach lub w karetkach pogotowia.

W kardiologii echokardiografia jest podstawowym, wykorzystywanym na co dzień narzędziem diagnostycznym, zarówno w badaniach wykonywanych w trybie planowym, jak i nagłym przy łóżku pacjenta w salach intensywnego nadzoru kardiologicznego. Od dawna jest cenioną metodą wykrywania obecności płynu w jamach ciała, między 


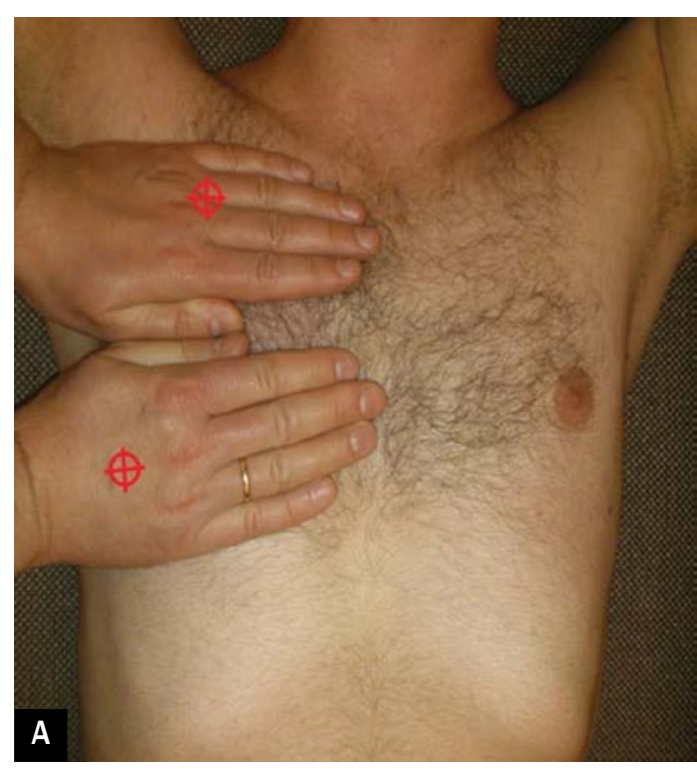

Rycina 1A. Punkty BLUE przedni górny i dolny; B. Punkt PLAPS

innymi w jamach opłucnowych. Przez wiele lat panował pogląd o małej przydatności ultradźwięków w diagnostyce narządów powietrznych, takich jak płuca. W latach 90. ubiegłego wieku pojawiły się prace opisujące ultrasonograficznie wykryte objawy w zapaleniu płuc, obrzęku płuc, odmie opłucnowej. Zaproponowano zastosowanie USG do szybkiej diagnostyki pacjentów w stanie zagrożenia życia. Przykładem mogą być protokoły Focused Assessment with Sonography in Trauma (FAST), Bedside Lung Ultrasonography in Emergency (BLUE), Focused Echo Evaluation in Resuscitation (FEER) czy Focused Assessment Transthoracic in Emergency (FATE) [1, 2].

\section{Wyposażenie pracowni}

Uważa się, że do badania klatki piersiowej można użyć aparatu USG wyposażonego w podstawowe funkcje oraz jedną z głowic: sektorową, konweksową lub liniową. Każda z nich ma swoje zalety. Głowica liniowa - ze względu na wysoką częstotliwość fal ultradźwiękowych - lepiej obrazuje płytkie warstwy. Pozwala to dokładnie ocenić linię opłucnej, objaw „ślizgania” wykluczający odmę opłucnową, zmiany zapalne i ogniskowe bezpośrednio przylegające do opłucnej. Głowice konweksowe i sektorowe zaś stosuje się do obserwacji głębszych warstw - do uwidocznienia płynu w opłucnej, linii B, obszarów konsolidacji tkanki płucnej. Umożliwiają, choć z mniejszą rozdzielczością, ocenę linii opłucnej i objawu „ślizgania”. U pacjentów w ciężkim stanie, w warunkach sali intensywnego nadzoru, dobrze sprawdzają się kardiologiczne głowice sektorowe. Mają niewielkie rozmiary i małą powierzchnię przyłożenia, dlatego łatwo nimi manewrować w przestrzeniach międzyże-

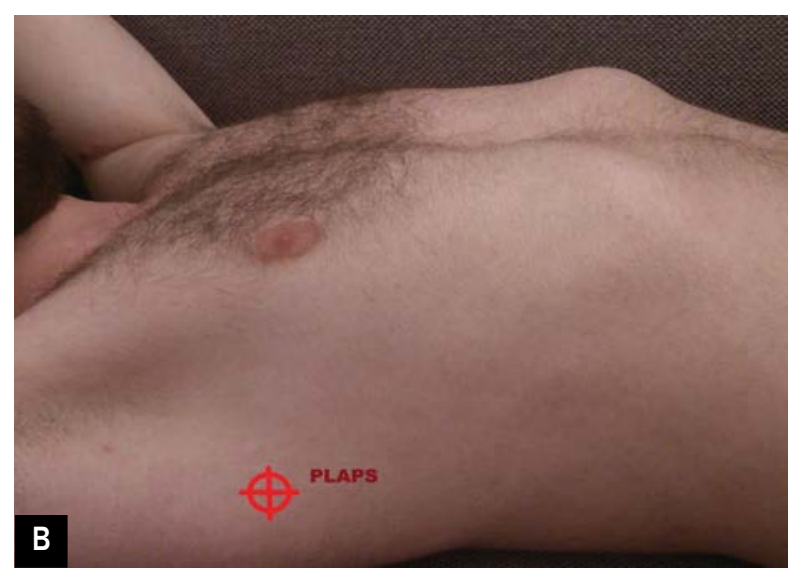

browych i w trudno dostępnych miejscach. Nie wszystkie aparaty USG mają wstępne ustawienia, tak zwane presety, dedykowane przezklatkowemu badaniu płuc. Przy zastosowaniu głowic konweksowych wykorzystuje się ustawienia do badania jamy brzusznej. W przypadku głowicy sektorowej zalecane są ustawienia do badań serca lub jamy brzusznej. Stosując głowicę liniową, używa się ustawień do badania narządów powierzchownych. Należy dostosować podstawowe parametry, takie jak wzmocnienie, głębokość badania, ognisko ultradźwięków. Przezklatkowe USG płuc opiera się na analizie artefaktów powstających na granicy ośrodków o różnej impedancji dla fal ultradźwiękowych. W nowoczesnych ultrasonografach wykorzystujących zaawansowane technologie obrazowania, takie jak częstotliwość harmoniczna czy ultradźwięki skrzyżowane, które wpływają na redukcję powstawania artefaktów, może zajść konieczność wyłączenia tych opcji.

\section{Technika badania}

Pacjent w trakcie badania USG płuc może przebywać w pozycji leżącej, stojącej lub siedzącej. Na potrzeby badania szczegółowego głowice przykłada się w wybranych miejscach klatki piersiowej i porównuje obrazy z symetrycznymi miejscami po drugiej stronie klatki piersiowej. Fizjologicznymi oknami akustycznymi są: przestrzenie międzyżebrowe, doły nadobojczykowe, okolica wcięcia mostka, narządy miąższowe jamy brzusznej (wątroba i śledziona), patologiczne okna akustyczne, na przykład konsolidacje tkanki płucnej, płyn w opłucnej, płyn w osierdziu, guzy śródpiersia przylegające do ściany klatki piersiowej [3]. W przypadku stanów zagrożenia życia zaleca się przyłożenie głowicy 
w określonych punktach według protokołu BLUE (opracowanego przez Daniela Lichtensteina) (ryc. 1A). Do praktycznego wyznaczenia tych punktów używa się dłoni umieszczonych na klatce piersiowej w ten sposób, aby piąty palec górnej dłoni znajdował się pod obojczykiem, a czubki palców na linii pośrodkowej mostka. Punkt górny przedni to miejsce u podstawy między III a IV palcem. Punkt przedni dolny wyznacza środek dolnej dłoni. Trzeci punkt określany jako PLAPS (posterolateral alveolar and/or pleural syndrome) to miejsce prostopadłego skrzyżowania linii pachowej tylnej i linii przecinającej punkt przedni dolny [4] (ryc. 1B).

\section{Główne artefakty i objawy ultrasonograficzne oceniane podczas badania płuc}

Objaw nietoperza (bat sign) to obraz przypominający przekrój nietoperza w locie, powstający po przyłożeniu głowicy USG poprzecznie do przebiegu międzyżebrza. Na zewnątrz obrazu widoczne są dwa cienie akustyczne żeber oraz leżąca około $5 \mathrm{~mm}$ niżej hiperechogeniczna pozioma linia opłucnej. Ten charakterystyczny obraz jest artefaktem powstającym na skutek intensywnych odbić fal ultradźwiękowych na granicy dobrze uwodnionych i dobrze przewodzących ultradźwięki tkanek powierzchownych klatki piersiowej i upowietrznionej tkanki płucnej o wysokiej impedancji dla ultradźwięków (ryc. 2A).

Linie A to artefakt o charakterze rewerberacji. Są to wielokrotnie powtarzające się w tej samej odległości od siebie poziome hiperechogeniczne linie równoległe do linii opłucnej. Odległość między nimi odpowiada odległości pomiędzy powierzchnią klatki piersiowej a linią opłucnej [5] (ryc. 2B).

Objaw „ślizgania” (sliping sign) to dynamiczny artefakt powstający na linii opłucnej, w wyniku przemieszczania się zgodnie z akcją oddechową i zmianą objętości płuca, opłucnej płucnej względem nieruchomej opłucnej ściennej [5]. W opcji M-mode objaw ten jest określany jako obraz „plaży” (seashore sign) (ryc. 2C).

Artefakt linii B jest artefaktem (comet tail artifact) o charakterze rewerberacji, powstaje w wyniku wielokrotnych odbić fal ultradźwiękowych od ośrodków o różnej impedancji akustycznej. Jego pojawienie wiąże się ze zwiększeniem ilości płynu w przegrodach międzypęcherzykowych płuc. Na ekranie ultrasonografu są widoczne jako hiperechogeniczne pionowe linie mające początek na linii opłucnej i biegnące przez całą długość ekranu. Poruszają się wraz z linią opłucnej w czasie oddychania. Nie występują razem z liniami $A[5,6]$ (ryc. 2D).

Obraz czworokąta (quad sign) jest objawem obecności płynu w jamie opłucnowej. Czworokąt tworzą linia opłucnej, powierzchnia płuca oraz bocznie cienie akustyczne żeber.

Objaw sinusoidy (sinusoid sign) widoczny w prezentacji M-mode to charakterystyczny objaw falowania linii opłucnej powstający na skutek zmian objętości przestrzeni płynowej w czasie ruchów oddechowych.

Objaw stratosfery (stratosphere sign) obserwowany w prezentacji M-mode jest typowy dla odmy opłucnowej, polega na zaniku ruchu linii opłucnej i zastąpieniu prawidłowego objawu „plaży” poziomymi hiperechogenicznymi liniami.

Lung point to miejsce oznaczające granice odmy opłucnowej i prawidłowo upowietrznionego płuca. Na ekranie ultrasonografu pojawia się na zmianę w rytm ruchów oddechowych obraz typowy dla odmy i prawidłowego płuca (ryc. 2E).

Linie T lung puls pojawiają się w przypadku niedodmy. Charakterystyczne pionowe artefakty w „obrazie stratosfery” zaczynające się na poziomie linii opłucnej są wynikiem przewodzenia przez niedodmowe płuco fal dźwiękowych wywołanych biciem serca. Stwierdzenie tego objawu potwierdza brak powietrzności płuca i wyklucza odmę opłucnową (ryc. 2F).

Objaw „zwątrobienia płuc” powstaje na skutek utraty powietrzności płuca, które w obrazie USG przypomina echostrukturą wątrobę lub śledzionę. Obraz taki jest typowy dla późnej fazy niedodmy (ryc. 3A).

Obraz „kłaczkowania” (shred sign) oznacza zatartą granicę między upowietrznionym miąższem płuca a obszarem konsolidacji [7] (ryc. 3B).

Bronchogram powietrzny statyczny - objaw typowy dla późnej fazy niedodmy. Wynika z odbić ultradźwięków od resztek powietrza uwięzionego w drogach oddechowych. Objawia się drobnymi hiperechogenicznymi, ziarnistymi echami w obrębie niedodmy nieporuszającymi się w trakcie ruchów oddechowych [7, 8] (ryc. 3C).

Bronchogram powietrzny dynamiczny jest charakterystyczny dla konsolidacji tkanki płucnej. Powstaje w wyniku odbić od powietrza uwięzionego w dystalnych drogach oddechowych. Objawia się ziarnistymi, hiperechogenicznymi artefaktami poruszającymi się w trakcie ruchów oddechowych $[5,7]$.

Bronchogram płynowy oznacza obecność płynu wysiękowego w drogach oddechowych i sugeruje niedrożność oskrzela. W obszarach konsolidacji tkanki płucnej widoczne są bezechowe linijne lub tabularne struktury. W obrazie USG mogą przypominać naczynia krwionośne płuc. W celu różnicowania można wykorzystać opcje dopplerowskie, takie jak dopler kolorowy i dopler mocy [5].

Artefakty linii I i Z - ich znaczenie kliniczne nie zostało określone. Przyjmuje się, że mogą występować w obrazie USG zdrowego płuca. Mają charakter artefaktu ogona komety i są podobne do linii B, zaczynają się na poziomie linii opłucnej. W odróżnieniu od linii B nie sięgają do końca ekranu. Kończą się 1-2 cm pod linią opłucnej lub w 1/2 ekranu, mogą współistnieć z liniami A. 


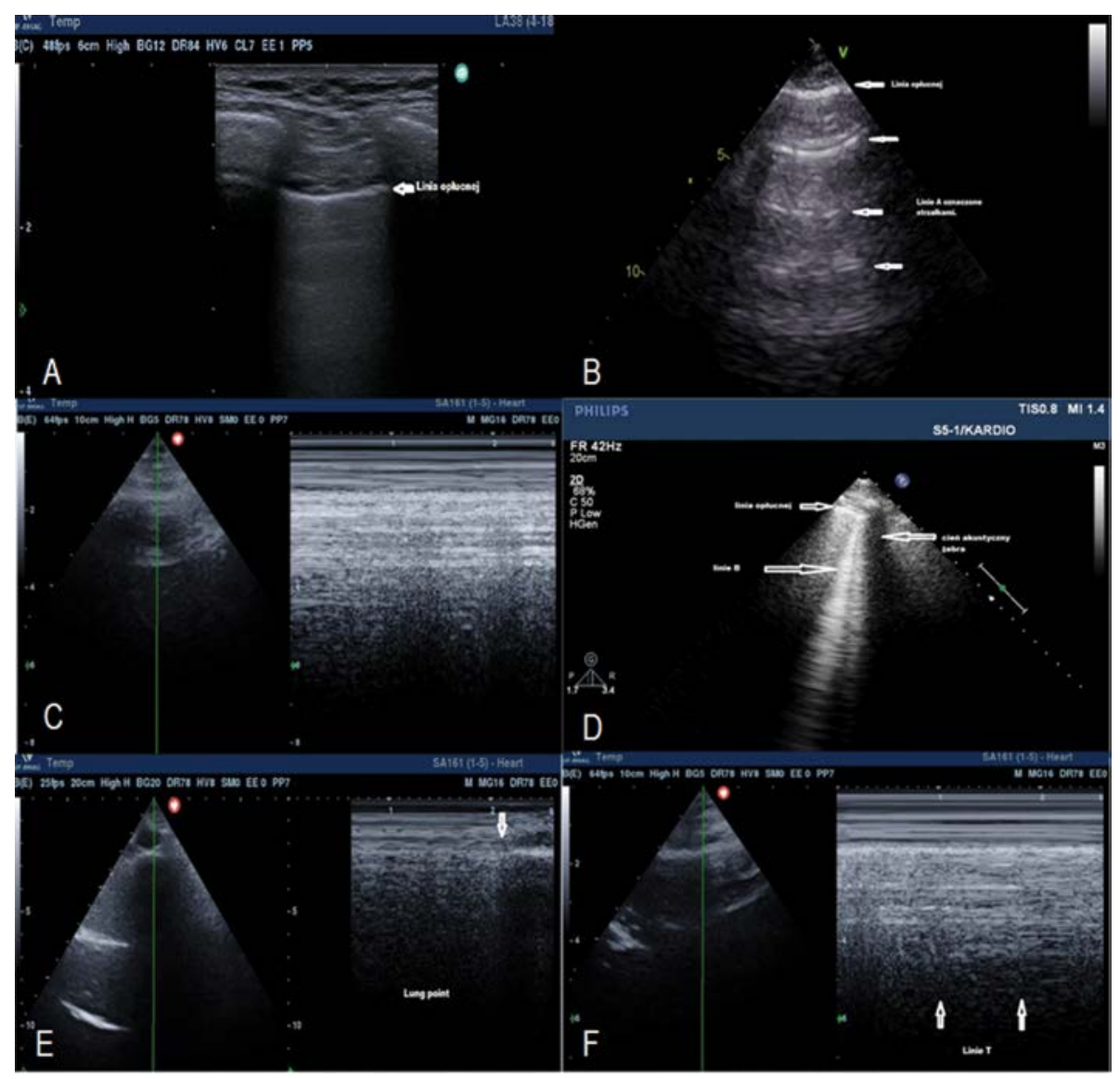

Rycina 2A. Linia opłucnej - objaw „nietoperza”; B. Linie A; C. Objaw „plaży”; D. Linie B; E. Objaw lung point; F. Linie T

\section{Prawidłowy obraz płuc}

\section{w przezklatkowym badaniu USG}

Na prawidłowy obraz płuc składają się: obecność objawu „Ślizgania” linii opłucnej oraz artefaktów linii A. Mogą też występować artefakty linii Z, które są widoczne w $80 \%$ badań. W tylno-dolnych segmentach płuc mogą występować pojedyncze linie $B[5,9]$.

\section{Niewydolność serca}

\section{w przezklatkowym badaniu USG płuc}

Niewydolność serca jest częstą przyczyną hospitalizacji pacjentów na oddziałach kardiologicznych i internistycznych. Typowym badaniem obrazowym wykonywanym w takim przypadku jest badanie radiologiczne (RTG) klatki piersiowej. Poszukuje się w nim objawów świadczących o zwiększeniu ilości płynu w przestrzeni pozanaczyniowej płuc. W latach 90. XX wieku pojawiły się doniesienia o przydatności przezklatkowego badania USG w ocenie pacjentów z niewydolnością serca.

Linie B odpowiadają radiologicznym liniom Kerleya w RTG klatki piersiowej. Dowiedziono, że ilość linii B zależy od stopnia uwodnienia płuc. Ich liczba wzrasta proporcjonalnie do ilości pozanaczyniowej wody płucnej, klasy niewydolności według skali Nowojorskiego Towarzystwa Kardiologicznego (NYHA, New York Heart Association) i stężenia peptydu natriuretycznego oraz ciśnienia zaklinowania w tętnicy płucnej $[5,8,10]$. Liczba linii $B$ po podaniu diuretyków lub $w$ trakcie dializy u pacjentów z obrzękiem płuc w ciągu kilku minut dynamicznie się zmniejsza, rośnie zaś w przypadku nasilenia ostrej niewydolności serca [11].

Aby oszacować pótilościowo stopień uwodnienia płuc, ocenia się obecność i sumuje liczbę linii B symetrycznie po obu stronach klatki piersiowej w liniach: przymostkowych, środkowo-obojczykowych, pachowych przednich i środkowych w przestrzeniach międzyżebrowych II-V po prawej stronie i w przestrzeniach międzyżebrowych II-IV po stronie lewej. Z każdego z tych punktów przyłożenia głowicy USG podaje się liczbę linii B: od 0 - gdy są one nieobecne, do maksymalnie 10 - gdy pokrywają cały sektor obrazu.

Zespół prof. Picanto w pracach nad stopniem uwodnienia płuc wykazał zależność liczby linii B w przezklatkowym badaniu USG płuc od ilości pozanaczyniowej wody płucnej (EVLW, extravascular lung water) (tab. 1) [12].

Metode obserwacji liczby linii B w przezklatkowym badaniu USG płuc uznaje się jako prostą technicznie i powtarzalną, wskazaną zwłaszcza do rozpoznawania oraz 

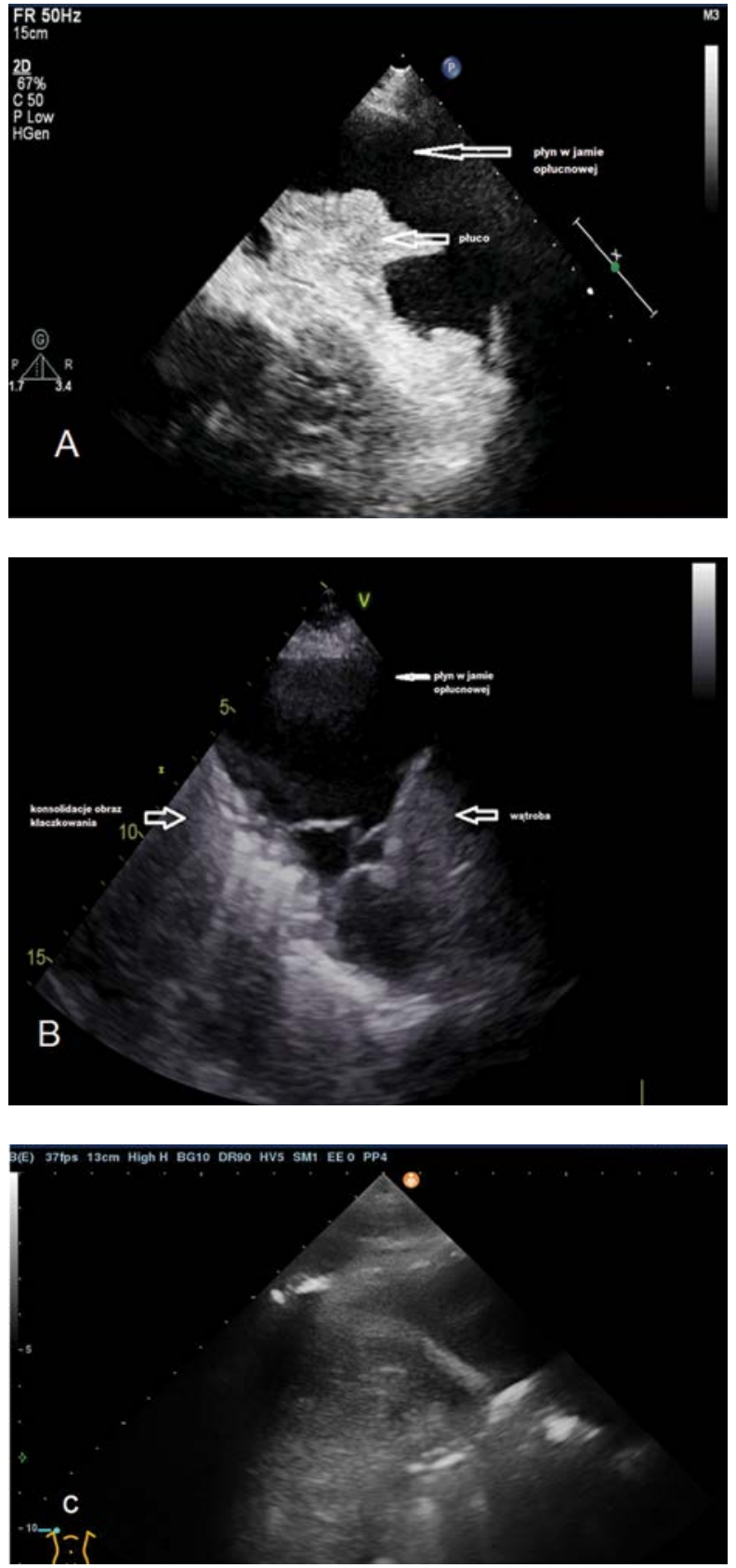

Rycina 3A. Objaw „zwątrobienia pluc”; B. Obraz „kłaczkowania”; C. Bronchogram powietrzny

monitorowania postępów leczenia ostrej lub zaostrzonej niewydolności serca.

\section{Płyn w jamach opłucnowych}

Ultrasonografia od kilkudziesięciu lat jest uznaną metodą wykrywania i szacowania ilości płynu w jamach opłucnowych oraz wyznaczania optymalnego miejsca do torakocentezy. Coraz częściej USG wykorzystuje się do bezpośredniego monitorowania tego zabiegu. Doskonała przewodność ultradźwięków w wodzie sprawia, że nawet małe ilości
Tabela 1. Stopnie uwodnienia i ilość pozanaczyniowej wody płucnej (EVLW, extravascular lung water) według prof. Picanto (źródło [12])

$\begin{array}{lcc}\text { Stopień uwodnienia } & \text { Liczba linii B } & \text { Ilość EVLW } \\ 0 & \leq 5 & \text { Brak } \\ 1 & 6-15 & \text { Mała } \\ 2 & 16-30 & \text { Średnia } \\ 3 & >30 & \text { Duża }\end{array}$

Tabela 2. PLAPS index według Daniela Lichtensteina [7]

\begin{tabular}{|lc}
\hline $\begin{array}{l}\text { PLAPS index } \\
\text { (warstwa płynu) [mm] }\end{array}$ & $\begin{array}{c}\text { Objętość płynu } \\
\text { w opłucnej [ml] }\end{array}$ \\
\hline 10 & $75-150$ \\
20 & $300-600$ \\
35 & $>1500$ \\
\hline
\end{tabular}

płynu w jamach ciała są widoczne w badaniach USG. W wykonanym w pozycji stojącej zdjęciu RTG można wykazać wysięk o pojemności 200-300 ml, w pozycji leżącej -300-500 ml, za pomocą USG zaś możliwe jest wykrycie wysięku o objętości $30 \mathrm{ml}$ [13].

Na obraz USG płynu w opłucnej składają się następujące objawy:

- czworokąta;

- sinusoidy.

Oceniając echogeniczność płynu, można wnioskować o jego charakterze. Zupełnie bezechowy płyn jest zwykle przesiękiem. Stwierdzenie w płynie drobnych „nitkowatych” ech może sugerować wysięk. Duża ilość poruszających się w płynie hiperechogenicznych „punkcikowatych” ech może wskazywać na ropniaka opłucnej lub krwawienie do jamy opłucnowej. Płyn z lito-płynowymi obszarami o zmiennej liczbie i proporcjach może oznaczać krwiaka opłucnej lub ropniaka [ryc. 4C, D].

llość płynu w opłucnej można oszacować, mierząc maksymalną odległość między blaszkami opłucnej, i wyliczyć ze wzoru [14]:

$\mathrm{V}[\mathrm{ml}]=20 \times \operatorname{Sep}[\mathrm{mm}]$,

gdzie: V - objętość płynu w ml, Sep - maksymalna odległość między blaszkami opłucnej w mm.

Do szybkiej oceny ilości płynu w opłucnej może służyć zaproponowany przez Daniela Lichtensteina PLAPS index. Na podstawie pomiaru grubości warstwy płynu między linią opłucnej a powierzchnią płuca w punkcie PLAPS na wydechu empirycznie określono ilości płynu uzyskane w czasie torakocentezy (tab. 2) [7].

\section{Konsolidacje tkanki płucnej}

Na skutek toczących się w tkance płucnej patologicznych procesów prowadzących do utraty powietrzności, takich 


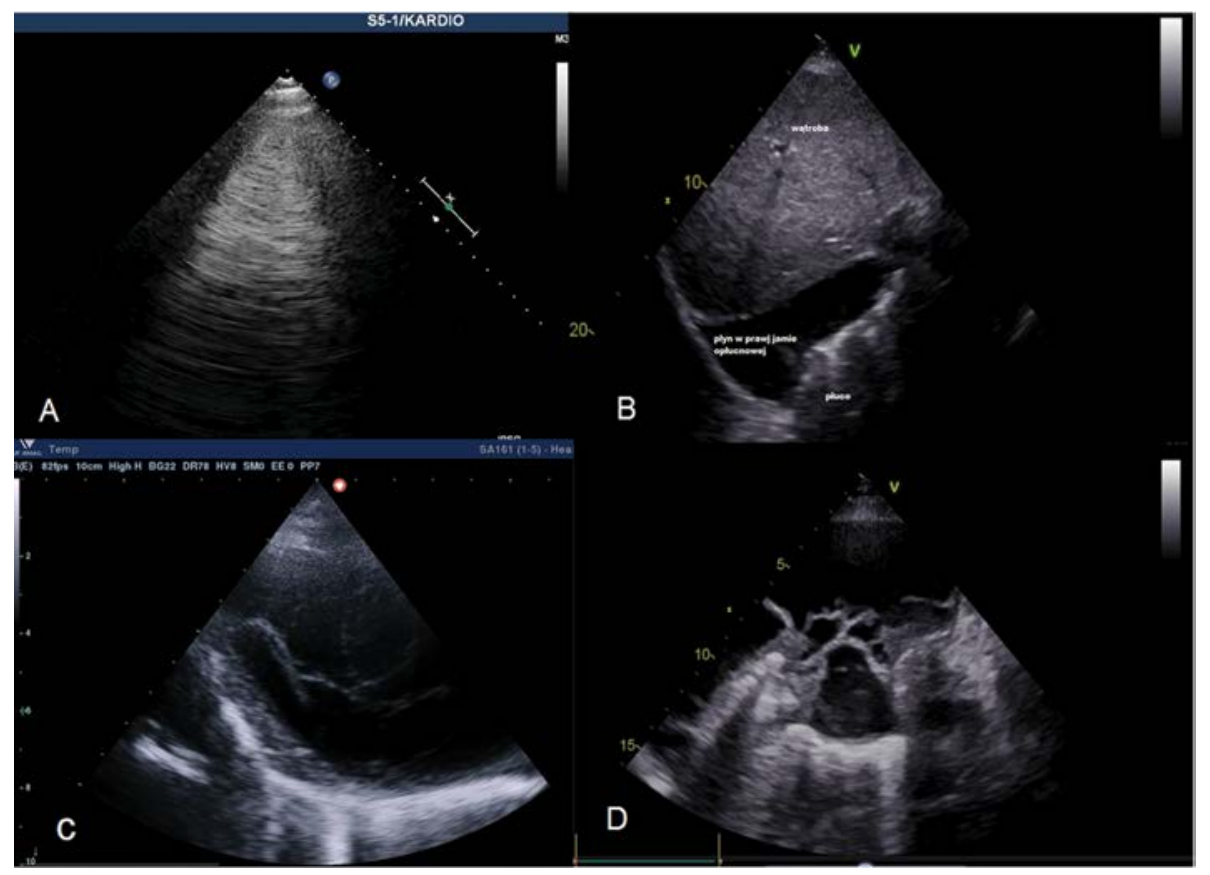

Rycina 4.A. Obrzęk płuc, liczne linie B tworzące obraz białego płuca; B. Bezechowy płyn w prawej jamie opłucnowej; C. Krwiak opłucnej (przykład pacjenta po urazie nożem klatki piersiowej); D. Płyn z obecnością przegród i pasm włóknika

jak proces zapalny, guz, zatorowość czy ognisko stłuczenia, w obrazie USG płuc można uwidocznić tak zwane konsolidacje. W $90 \%$ przypadków zmiany te przylegaja do powierzchni opłucnej. Wówczas bezpowietrzna tkanka płucna przewodzi ultradźwięki, co daje możliwość zaobserwowania typowych zmian w badaniu USG. Obecność prawidłowej (upowietrznionej) tkanki płucnej między konsolidacjami i opłucną uniemożliwia zobrazowanie tych zmian $[15,16]$.

Charakterystycznymi objawami występującymi w tym przypadku są:

- objaw "zwątrobienia płuc”;

- obraz „kłaczkowania”;

- bronchogram powietrzny dynamiczny;

- bronchogram płynowy.

\section{Niedodma}

Do niedodmy dochodzi w skutek utraty powietrzności płuca na skutek ucisku z zewnątrz (np. przez płyn) lub utraty drożności oskrzela (ciało obce, guz w świetle oskrzela). We wczesnej fazie niedodmy, gdy w oskrzelach obecna jest niewielka ilość powietrza, występują następujące objawy ultrasonograficzne:

- zanika objaw „ślizgania” opłucnej;

- brak typowego objawu „plaży”, pojawiają się linie „T";

- zanika prawidłowa ruchomość przepony.

Po wchłonięciu się powietrza z dróg oddechowych w późnej fazie niedodmy można zaobserwować następujące objawy ultrasonograficzne:

- objaw „zwątrobienia płuc”;
- obraz „kłaczkowania”;

- statyczny bronchogram powietrzny.

\section{Odma opłucnowa}

Obecność powietrza między obiema blaszkami opłucnej określa się jako odmę. Ze względu na przyczynę można ją podzielić na samoistną, pourazową i jatrogenną. Odma samoistna jest spowodowana pęknięciem pęcherzyków płucnych lub pęcherza rozejmowego leżącego podopłucnowo. Odma pourazowa wynika z poważnych urazów komunikacyjnych, upadku z wysokości lub ugodzenia ostrym przedmiotem. Odma jatrogenna jest powikłaniem po takich zabiegach, jak torakocenteza, biopsja płuca, implantacja stymulatora serca, kaniulacja żył centralnych: podobojczykowych lub szyjnych. Rutynowymi badaniami stosowanymi do wykrycia odmy opłucnowej są RTG i tomografia komputerowa (CT, computed tomography) klatki piersiowej. Do szybkiej przyłóżkowej diagnostyki odmy, zwłaszcza u pacjentów w ciężkim stanie, po urazach lub sztucznie wentylowanych, przydatne jest badanie USG $[17,18]$.

Charakterystyczne objawy ultrasonograficzne sugerujące odmę to:

- brak objawu „ślizgania” opłucnej;

- objaw „stratosfery”;

- dominujące linie A;

- objaw lung point.

Objaw lung point wyznacza granicę między zapadniętym a prawidłowym płucem i z dużym prawdopodobieństwem potwierdza odmę. Może być nieobecny w przypadku dużej odmy prężnej, gdy płuco jest całkowicie spadnięte $[7,19]$. 


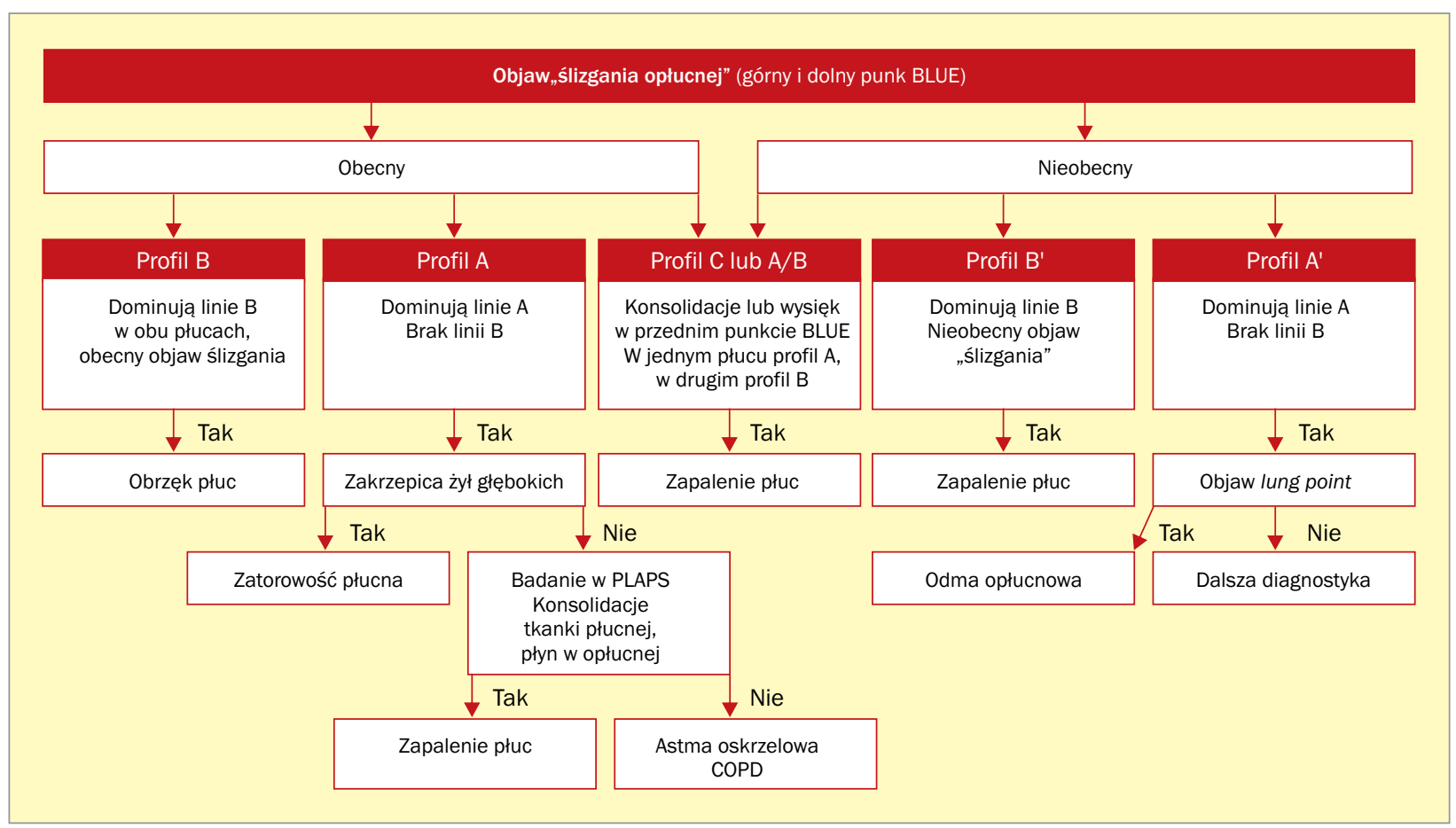

Rycina 5. Protokół BLUE (Bedside Lung Ultrasonography in Emergency) [6]; PLAPS (posterolateral alveolar and/or pleural syndrome) prostopadłe skrzyżowanie linii pachowej tylnej i linii przecinającej punkt przedni dolny; COPD (chronic obstructive pulmonary disease) przewlekła obturacyjna choroba płuc

Stwierdzenie prawidłowego objawu „ślizgania” opłucnej lub obecność linii B wyklucza odmę opłucnową.

\section{Protokół BLUE}

Zaproponowany w 2008 roku przez Daniela Lichtensteina protokół o akronimie BLUE [6] pozwala zróżnicować 5 najczęściej występujących przyczyn ostrej niewydolności oddechowej. Przyłóżkowe badanie USG klatki piersiowej w połączeniu z oceną USG żył głębokich kończyn dolnych pod kątem obecności zakrzepicy może z dużym prawdopodobieństwem potwierdzić lub wykluczyć: obrzęk płuc, zatorowość płucną, zapalenie płuc, odmę płuc, przewlekłą obturacyjną chorobę płuc (COPD, chronic obstructive pulmonary disease) lub astmę oskrzelowa. Badanie trwa około 3 min i ogranicza się do oceny ultrasonograficznej płuc w 6 standardowych punktach na przedniej i bocznej powierzchni klatki piersiowej w tak zwanych punktach BLUE (ryc. 5).

Profil B z zachowanym objawem „Ślizgania” opłucnej sugeruje ostry obrzęk płuc z 97-procentową czułością i 95-procentową specyficznością. Profil A związany z zakrzepicą żył głębokich i z zachowanym objawem „ślizgania” opłucnej wskazuje na zatorowość płucną z czułością wynosząca 81\% i swoistością - 99\%. Profil C, profil A z zachowanym objawem „ślizgania” opłucnej, bez zakrzepicy żył głębokich i zmianami w PLAPS, oraz profil B' bez zachowanego objawu „Ślizgania” opłucnej są typowe dla zapalenia płuc. Profil A z zachowanym objawem „ślizgania” opłucnej bez zakrzepicy żył głębokich i zmian w PLAPS może sugerować ciężką astmę lub zaostrzenie COPD. Profil A' z nieobecnym objawem „ślizgania" oraz z objawem lung point jest specyficzny dla odmy opłucnowej [6].

\section{Wnioski}

Badanie USG płuc jest łatwą do wykorzystania metodą diagnostyczną zarówno $w$ warunkach pracowni ultrasonograficznej, echokardiograficznej, jak i przyłóżkowo w warunkach sali intensywnego nadzoru kardiologicznego. Pozwala na ustalenie w krótkim czasie wstępnego rozpoznania u pacjentów z ostrą niewydolnością oddechową przy wykorzystaniu protokołu BLUE, jeszcze przed wykonaniem badań rentgenowskich. Wielokrotne powtarzanie badania umożliwia monitorowanie efektów prowadzonej terapii. Przeprowadzenie USG płuc pozwala na wgląd w patofizjologię układu oddechowego i krążenia pacjenta, jest cennym uzupełnieniem badania podmiotowego i przedmiotowego.

\section{Finansowanie}

Brak źródeł finansowania.

\section{Konflikt interesów}

Autorzy nie zgłaszają konfliktu interesów. 


\section{Abstract}

Echocardiography is a basic tool of medical diagnosis commonly used in cardiology. For many years, it was believed that ultrasound was of insignificant applicability in diagnosis of respiratory system organs such as lungs. It appears, however, that lung ultrasound (LUS) is an easily applicable diagnostic method used both in an ultrasound room and for bedside treatment in cardiac intensive care units. LUS ultrasound allows to make a prompt preliminary diagnosis in patients with acute respiratory failure even before $X$-ray tests. Severally repeated ultrasound tests facilitate monitoring the effects of applied treatment. The current state of knowledge concerning this ultrasound technique has been summarized herein. Key words: transthoracic chest ultrasound, cardiological i non-cardiological dyspnea

Folia Cardiologica 2017; 12, 5: 459-466

\section{Piśmiennictwo}

1. Moore CL, Copel JA. Point-of-care ultrasonography. N Engl J Med. 2011; 364(8): 749-757, doi: 10.1056/NEJMra0909487, indexed in Pubmed: 21345104.

2. Andruszkiewicz P. Ultrasound applications during cardiopulmonary resuscitation and in intensive care. FEEL and FATE Protocols. Ultrasonografia. 2011(45): 34-37.

3. Kosiak W. Chest ultrasound in the diagnosis of selected lung diseases in children. Rozprawa habilitacyjna Ann Acad Med. Gedan. 2013; 43(10): 1-165.

4. Lichtenstein D, Mezière G. The BLUE-points: three standardized points used in the BLUE-protocol for ultrasound assessment of the lung in acute respiratory failure. Crit Ultrasound J. 2011; 3(2): 109-110, doi: 10.1007/s13089-011-0066-3.

5. Kosiak W. Ultrasound in diagnosis of infectious diseases of respiratory system. Part 1. Ultrasound image of normal lungs. First attempt to ultrasound examination of infectious diseases of respiratory system. Ultrasonografia. 2009; 37: 26-31.

6. Lichtenstein D. Lung ultrasound in the critically ill. Ann Intensive Care. 2014; 4(1): 1, doi: 10.1186/2110-5820-4-1.

7. Sobczyk D, Andruszkiewicz P, Andres J. Ultrasonografia w stanach zagrożenia życia i intensywnej terapii. Polska Rada Resuscytacji, Kraków 2012: 217-233.

8. Igielska B, Buda N, Kosiak W. Chest ultrasonography for the diagnosis of cardiogenic edema - review of the literature. Ultrasonografia. 2011(11): 44.

9. Koenig SJ, Narasimhan M, Mayo PH. Thoracic ultrasonography for the pulmonary specialist. Chest. 2011; 140(5): 1332-1341, doi: 10.1378/chest.11-0348, indexed in Pubmed: 22045878.
10. Gościniak P. Ultrasonograficzna ocean uwodnienia płuc. Kardiologia Po Dyplomie. 2014; 13(7-8): 50-52.

11. Lee J. Lung Ultrasound in Critically III Patients. Korean J Crit Care Med. 2016; 31(1): 4-9, doi: 10.4266/kjccm.2016.31.1.4.

12. Gargani L. Lung ultrasound: a new tool for the cardiologist. Cardiovasc Ultrasound. 2011; 9: 6, doi: 10.1186/1476-7120-9-6, indexed in Pubmed: 21352576.

13. Kremer H, Dobrinski W. Diagnostyka ultrasonograficzna. Wrocław, Urban \& Partner 1996: 333-341.

14. Stefanidis K, Dimopoulos S, Nanas S. Basic principles and current applications of lung ultrasonography in the intensive care unit. Respirology. 2011; 16(2): 249-256, doi: 10.1111/j.1440-1843.2010.01885.x, indexed in Pubmed: 20969673.

15. Kosiak W. Progress in lung ultrasound in the end of 2009. Ultrasonografia. 2009(39): 57-61.

16. Kosiak W. Ultrasound in diagnosis of infectious diseases of respiratory system. Part 2. Ultrasound images of pneumonia. Ultrasonografia. 2009; 37: 32-37.

17. Ashton-Cleary DT. Is thoracic ultrasound a viable alternative to conventional imaging in the critical care setting? Br J Anaesth. 2013; 111(2): 152-160, doi: 10.1093/bja/aet076, indexed in Pubmed: 23585400.

18. Zanobetti M, Poggioni C, Pini R. Can chest ultrasonography replace standard chest radiography for evaluation of acute dyspnea in the ED? Chest. 2011; 139(5): 1140-1147, doi: 10.1378/chest.10-0435, indexed in Pubmed: 20947649.

19. Perera P, Mailhot T, Riley D, et al. The RUSH Exam 2012: rapid ultrasound in shock in the evaluation of the critically ill patient. Ultrasound Clin. 2012; 7(2): 255-278, doi: 10.1016/j.cult.2011.12.010. 